\title{
Chapter 8 \\ Irregular Migration and Irregular Work: A Chicken and Egg Dilemma
}

\author{
Anna Triandafyllidou and Laura Bartolini
}

\subsection{Introduction}

Irregular employment is a multifaceted phenomenon, which spans from totally undeclared work (paid lawful activities not declared to public authorities) to activities involving organized networks that engage in illicit economic activities (e.g. smuggling of goods, drug trafficking, or other criminal activities). Under certain circumstances, the presence of irregular work may be widely accepted and not even be perceived by citizens as outside of the law properly speaking, especially in countries where the informal economy is a sizeable phenomenon (Williams et al. 2017). However, irregular employment that involves foreign workers is a target of significant national and international political debate leading to policy actions in the fields of immigration and labour market regulations in most of European countries for over 20 years now (OECD 2000). The connection between undeclared work and irregular migration often combines in an explosive mix that stirs anxieties about state's control over migration flows, labour market regulation, unfair competition with native workers, and lost revenues for the state.

Although rough and volatile, estimates on the size of irregular migration in Europe point to a quite limited phenomenon involving between 1.9 and 3.8 million people in 2008 (Kovacheva and Vogel 2009). However, according to most analysts

This chapter draws on previous work of the authors, in particular Triandafyllidou and Bartolini (2016, 2017).

The opinions expressed in this chapter are those of the authors and do not necessarily reflect the views of the International Organization for Migration (IOM).

\footnotetext{
A. Triandafyllidou $(\bowtie)$

Department of Sociology, Faculty of Arts, Ryerson University, Toronto, ON, Canada

e-mail: anna.triandafyllidou@ryerson.ca
}

L. Bartolini

International Organization for Migration (IOM), Rome, Italy 
and scholars, this slowed during the economic and financial crisis to partially restart growing due to the most recent inflows of asylum seekers, refugees, and other migrants in Europe over the past 5 years.

Our theoretical understandings of irregular labour migration can still be summarised largely in what Portes (1978) called the "structural determinants in both sending and receiving countries": the demand for cheap, irregular labour in receiving countries coupled with the needs arising from increasing demographic and economic pressures of booming young populations in countries of origin. While there is a structural demand for migrant workers in a number of sectors-of mostly low skill, low prestige and low pay jobs (as those discussed in detail further below in this chapter) - related legal migration policies do not cater for such demand. Restrictive policies somehow 'generate' (De Genova 2004) illegal residence status and irregular work to the extent that they make it very difficult for both migrants and their employers to regularise their situation, having to face two hurdles: migration legislation and labour law.

Patterns of irregularity are extremely diversified, including children of undocumented parents, visa over-stayers, migrants who lost their legal status because of unemployment, and rejected asylum seekers (see also Triandafyllidou and Bartolini, Chap. 2). As migrating legally to the EU and other western countries has become increasingly difficult, scholars have argued that irregularity can be part of a labour market strategy promoted by governments to cater for the needs of employers for a cheap and plentiful workforce, particularly for some sectors of the domestic labour market and agriculture, in order to compress costs and increase profits (Jordan and Düvell 2002; Lewis et al. 2015; Kilkey and Urzi 2017; Palumbo and Sciurba 2018).

The current volatile geopolitical context-the post-Arab spring situation in North Africa and the Middle East, the protracted conflicts in parts of Asia (e.g. Afghanistan) and East Africa (Sudan, South Sudan, Eritrea, Yemen) as well as instability in Central and West Africa (Democratic Republic of Congo, Nigeria, Lake Chad basin), and the fragile recovery from the global financial and Eurozone crisis-have radically transformed international migration flows towards Europe. First of all, today we witness flows of migrants who have mixed motivations: they seek better employment and a better future for themselves and their families, but they also escape violence, conflict, insecurity (Galos et al. 2017). Second, there is an increasing participation of minors in these flows, particularly of adolescents who travel alone through the Eastern, Central and Western Mediterranean routes (UNHCR, UNICEF, and IOM 2018). Third, there is a continuous feminisation of flows catering for specific sectors such as domestic work and cleaning or catering as well as sex work. Fourth, the lack of regular entry channels and the long distances that migrants travel along with hardship faced along the route, make them particularly vulnerable and, indeed, desperate to find a job. There is a clear link between the restrictive labour migration and asylum-seeking policies in Europe and the presence of migrants with an insecure, temporary, or indeed irregular status (Triandafyllidou et al. 2019). Asylum seekers who are rejected on first instance or who are awaiting for their case to be processed, minors and women who do not receive adequate support or protection, and individuals with tolerated status 
represent a pool of people that is likely to accept irregular work out of necessity as they have no other option (Palumbo and Sciurba 2018; van Hear et al. 2009; Lewis and Waite 2015; Vickstrom 2014). Such workers are actually in demand in several European countries in specific sectors of the economy, spanning from agriculture to catering, tourism, and the retail industry, where irregular employment can contribute to lowering costs, increasing flexibility, and competitiveness.

The chapter's first aim is to highlight the complex and multifaceted relationship between irregular or temporary migration and irregular work by offering a typology of irregular/informal work and of statuses, and relationships between irregular migration and irregular work. In other words, we seek to systematise the alreadyexisting knowledge and data highlighting the dynamic relationship between the two phenomena. Second, we take a closer look into the overall inter-relationship between irregular work and both irregular and regular migration with a view to highlighting how migration policy may feed into irregular employment and facilitate the violation of migrants' labour rights. The chapter then turns to three sectors where informal work is widespread and where the irregular employment of migrants or the employment of irregular migrants abounds. We look closer into each sector to highlight the dynamics and conditions that breed these phenomena, examining how labour market needs interact with migrant labour offer and with migration and labour laws. The chapter concludes by highlighting the conditions that feed into irregular migrant work and teases out the relevant policy implications of our study.

\subsection{The Complex Relationship Between Irregular Work and Irregular Stay}

\subsubsection{Irregular Employment}

The notion of irregular employment is inextricably connected with the notion of informal economy, intended as the economic activities that are hidden from the authorities and non-compliant with relevant regulations and thus 'not-observed' or 'unknown' in terms of production and/or employment generated. Looking at internationally agreed definitions, the OECD speaks of informal employment any time "although not illegal in itself, \{employment $\}$ has not been declared to one or more administrative authorities" (OECD 2004). More explicit in excluding criminal activities, the European Commission defines undeclared work as "any paid activities that are lawful as regards their nature but not declared to public authorities, taking into account differences in the regulatory system of Member States" (EC 1998). In line with these approaches, our working definition of undeclared work excludes illegal activities (e.g. drug dealing, prostitution, black market of alcohol and cigarettes, etc.), irrespective from workers' migration status. As some of these activities are sometimes legal in a few EU countries, estimates presented in the 
Table 8.1 Informal economy by sector and production unity, activity, job type and status in employment

\begin{tabular}{|c|c|c|c|c|c|c|c|}
\hline \multirow{2}{*}{\multicolumn{3}{|c|}{ Sector of the economy and type of production }} & \multicolumn{5}{|c|}{ Job type and status in employment } \\
\hline & & & \multicolumn{2}{|c|}{$\begin{array}{l}\text { Self-employed with or } \\
\text { without employees }\end{array}$} & \multicolumn{2}{|c|}{ Employee } & \multirow{2}{*}{$\begin{array}{c}\begin{array}{c}\text { Contributing } \\
\text { family worker }\end{array} \\
\text { Irregular }\end{array}$} \\
\hline $\begin{array}{l}\text { Sector/ } \\
\text { Production } \\
\text { Unit }\end{array}$ & Activities & Definition & Irregular & Regular & Irregular & Regular & \\
\hline $\begin{array}{l}\text { Formal sector } \\
\text { enterprises: } \\
\text { firms, non-profit } \\
\text { institutions, } \\
\text { corporations etc. } \\
\text { formally } \\
\text { registered and } \\
\text { producing goods } \\
\text { or services for } \\
\text { the market }\end{array}$ & $\begin{array}{l}\text { Underground } \\
\text { activities }\end{array}$ & $\begin{array}{l}\text { Production of goods } \\
\text { and services legal but } \\
\text { deliberately concealed } \\
\text { from public authorities } \\
\text { to avoid payment of } \\
\text { income, taxes, or social } \\
\text { security contributions } \\
\text { and compliance with } \\
\text { certain legal standards } \\
\text { (hours \& shifts, safety/ } \\
\text { health standards, etc.) } \\
\text { or administrative } \\
\text { procedures, etc. }\end{array}$ & NA & $\begin{array}{l}\text { Registered } \\
\text { self- } \\
\text { employed } \\
\text { or employer } \\
\text { of } \\
\text { registered } \\
\text { entity }\end{array}$ & $\begin{array}{l}\text { 1. Under- } \\
\text { reported / } \\
\text { undeclared } \\
\text { paid } \\
\text { employee in } \\
\text { a registered } \\
\text { entity. }\end{array}$ & $\begin{array}{l}\text { Declared } \\
\text { employee } \\
\text { in a } \\
\text { registered } \\
\text { entity. }\end{array}$ & $\begin{array}{l}\text { 2. Family } \\
\text { worker } \\
\text { contributing to } \\
\text { a registered } \\
\text { entity. }\end{array}$ \\
\hline $\begin{array}{l}\text { Informal sector } \\
\text { enterprises: } \\
\text { private entities } \\
\text { totally } \\
\text { unregistered, } \\
\text { which produce } \\
\text { for the market. }\end{array}$ & $\begin{array}{l}\text { Informal } \\
\text { activities }\end{array}$ & $\begin{array}{l}\text { Productive activities, } \\
\text { conducted by } \\
\text { enterprises that may } \\
\text { take place within } \\
\text { household units, and are } \\
\text { not registered and/or are } \\
\text { less than a specified } \\
\text { size in terms of } \\
\text { employment. }\end{array}$ & $\begin{array}{l}\text { 3. Self- } \\
\text { employed } \\
\text { or } \\
\text { employer } \\
\text { in his own } \\
\text { informal } \\
\text { entity }\end{array}$ & NA & $\begin{array}{c}4 . \\
\text { Undeclared } \\
\text { paid } \\
\text { employee in } \\
\text { an informal } \\
\text { entity }\end{array}$ & NA & $\begin{array}{l}\text { 5. Family } \\
\text { worker in an } \\
\text { informal entity }\end{array}$ \\
\hline Household & $\begin{array}{l}\text { Production of } \\
\text { households }\end{array}$ & $\begin{array}{l}\text { Production of goods or } \\
\text { services consumed or } \\
\text { capitalised by the } \\
\text { household itself. }\end{array}$ & $\begin{array}{l}\text { 6. Self- } \\
\text { employed } \\
\text { for own } \\
\text { final use }\end{array}$ & NA & $\begin{array}{l}\text { 7. Under- } \\
\text { reported / } \\
\text { undeclared } \\
\text { paid } \\
\text { employee }\end{array}$ & $\begin{array}{l}\text { Declared } \\
\text { paid } \\
\text { domestic } \\
\text { worker }\end{array}$ & NA \\
\hline
\end{tabular}

Source: Authors' adaptation from (OECD 2002; Hussmanns 2004)

following pages will look at only transactions and activities that are considered equally lawful in all EU countries (Williams et al. 2017).

Without distinguishing between local and migrant workers, Table 8.1 presents a classifications of informal economy and informal employment (within firms or within households), focusing on the types and categories that are most relevant for the European economies. Even excluding unpaid and voluntary work and illegal activities, there is a wide range of irregular employment conditions that arise from different combinations of sectors, types of job, and status in employment. Thus, the table distinguishes between undeclared activities by regularly-registered firms that remain hidden/undeclared and informal activities that involve employment or production of goods or services by informal sector enterprises (totally unregistered and hence irregular).

The table also allows to distinguish among seven types of irregular employment conditions (see the second part of Table 8.1):

- Employees holding irregular jobs outside (1) and inside (4) the informal sector or employed as paid domestic workers by private households (7): the employment relationship is at least partially not covered by labour legislation, income taxation, social protection, and employment benefits. Depending on national laws, employees holding irregular jobs may include: employees without written contracts or not subject to labour legislation; workers who do not benefit from 
paid annual or sick leave, social security, or pension schemes; domestic workers employed by households; most casual, short-term, and seasonal workers. Informal employment can be totally or partially undeclared, if a portion of the salary (usually the legal minimum) is officially registered while the rest is paid "off the books".

- Self-employed workers with or without employees are irregularly employed in their own informal sector enterprises for the market (3) or for their own consumption (6), as by definition their condition of employment is defined by that of their enterprise. This category also includes members of informal producers' cooperatives, who can be assimilated to autonomous workers for the degree of risk/autonomy they face

- Contributing family workers are always considered as irregularly employed, irrespective of the type of enterprise (in case they are registered, they are classified as employees) ( $2 \& 5)$.

According to the ILO (2013), small shops and businesses, micro-manufacturing industries, warehouses, among subcontractors in the construction sectors and in agricultural activities. Under-declared work is even more frequent in industrialized economies and found in almost all sectors to avoid tax payment and decrease labour costs (for example paying under the table or not paying at all for nightshifts, weekend, or overtime work, but ensuring some social security coverage to workers by declaring the statutory minimum). The practice of subcontractors-used mostly in construction, transportation, logistics, and big commercial chains-often hides the use of cheap or undeclared labour hired by the subcontractor to replace regular, regulated and therefore more expensive, in-house employment. Temporary work agencies might also convey irregular practices in hiring and firing workers, while the extensive use of very short-term contracts for seasonal activities, on-call contracts, and voucher systems is generally found in the services sector (domestic and care, restaurants and hotels, entertainment, etc.). Finally, the practice of bogus or false employment is more common among highly-skilled, professional sectors where the presence of migrant workers is still rare across Europe; the widespread use of internships among young adults is likely to affect in high numbers both national and foreign prospective workers, and it is often more similar to unpaid work than to an on-the-job training period.

Indeed, irregular employment exists among local and migrant workers, with important implications at various levels. At the individual level, workers are excluded from social security coverage against the risk of illness, work injuries, unemployment, or age. Even when non-compliance with legal requirements is the result of an intended action of the workers-who might go for short-term benefits in-cash instead of long-term benefits in social security provisions-it implies some form of exclusion from what happens in the regular economy: higher vulnerability and more exposure to exploitation, low enforcement of labour rights, more insecurity and less continuity of employment or accruing of wages. This is true especially for low-skilled workers and less-qualified occupations, but it is not limited to them. At the structural level, irregular employment and the whole informal economy 
threatens the sustainability of welfare systems through a race to the bottom in standards and safeguards of formal enterprises to be competitive with informal ones through more deregulation and liberalization. In the long run, it reduces the quality of work and possibly the overall competitiveness in the global economy. ${ }^{1}$

The difficulty of referring to irregular employment in a single category, given the variety of possible combinations illustrated, becomes further complicated when the worker is a migrant and may or may not have the right to reside and work in the country.

\subsubsection{Irregular Work and Irregular Migrants: Multiple Dimensions}

Triandafyllidou and Bartolini in Chap. 2 of this volume have discussed the different types and degrees of 'irregularity' in relation to the residence status. The step further is to look at the possible ways in which irregular foreign residents and legallyresiding foreign residents are irregularly employed.

Table 8.2 distinguishes between possible citizenship and residence status, entitlement to work, and nature of employment of migrants of working-age within the European Union, seeking to produce a typology to understand where the irregular employment of irregular and regular migrants may arise.

The categories and conditions presented in Table 8.2 need to be understood in conjunction with the available knowledge on where the "most common expressions of undeclared work in the EU" lie (ILO 2013, 15-20), to unveil which are the combination between one's status in terms of residence and of employment that are most likely to be associated with vulnerability to exploitative conditions at the individual level which also create important challenges for the labour market in terms of controls and policy coordination. Indeed, migrants who find themselves in an irregular position both with regards with their residence and their employment condition are more likely to be found in certain specific sectors of the economy, as the next paragraph will further show, reinforcing dynamics of exclusion from the formal sphere of social and economic life migrants whose presence is somewhat known and tolerated from the authorities. ${ }^{2}$

\footnotetext{
${ }^{1}$ See the debated efforts to include estimates of informal and illegal economy into GDP figures at the European level (Merler and Hutl 2015).

${ }^{2}$ Practical examples of this toleration of irregular migrants by residence and inclusion with various degrees of regularity into local labour market are the case of Greece, which passed a law in 2016 to employ irregular migrants in agriculture to cope with farming needs (EMN 2016), and the case of Malta, in which the construction sector is known to extensively employ sub-Saharan migrants coming from Italy and in possess of an expiring Italian residence permit (see https://www.newsdeeply. com/refugees/articles/2018/08/06/migrants-malta-does-not-want-are-powering-its-economy).
} 
Table 8.2 Working-age migrants by possible residence and employment status

\begin{tabular}{|c|c|c|c|c|c|}
\hline Nationality & Residence status & $\begin{array}{l}\text { Registered by } \\
\text { authorities }\end{array}$ & $\begin{array}{l}\text { Entitlement } \\
\text { to work }\end{array}$ & $\begin{array}{l}\text { Nature of } \\
\text { employment }\end{array}$ & $\begin{array}{l}\text { Examples of } \\
\text { irregular } \\
\text { (undeclared/ } \\
\text { under-declared) } \\
\text { working conditions }\end{array}$ \\
\hline $\begin{array}{l}\text { EU } \\
\text { nationals }\end{array}$ & Right to reside & $\begin{array}{l}\text { Documented / } \\
\text { semi- } \\
\text { documented } \\
\end{array}$ & Yes & $\begin{array}{l}\text { Regular/ } \\
\text { irregular }\end{array}$ & $\begin{array}{l}\text { Undeclared or } \\
\text { under-declared, low } \\
\text { to highly skilled }\end{array}$ \\
\hline \multirow[t]{3}{*}{ TCNs } & $\begin{array}{l}\text { Residence permit: } \\
\text { permanent, } \\
\text { long-term, work, } \\
\text { family, study, } \\
\text { seasonal, } \\
\text { international and } \\
\text { national } \\
\text { protection etc. }\end{array}$ & Documented & Yes & $\begin{array}{l}\text { Regular/ } \\
\text { irregular }\end{array}$ & $\begin{array}{l}\text { Undeclared or } \\
\text { under-declared, low } \\
\text { to highly skilled: } \\
\text { some permits } \\
\text { provide the specific } \\
\text { number of hours to } \\
\text { be worked (study, } \\
\text { part-time work etc.) }\end{array}$ \\
\hline & $\begin{array}{l}\text { Pending (right to } \\
\text { stay \& wait): } \\
\text { ongoing } \\
\text { renewal } \\
\text { ongoing } \\
\text { regularization } \\
\text { ongoing } \\
\text { asylum } \\
\text { procedure }\end{array}$ & $\begin{array}{l}\text { Pending } \\
\text { procedure, } \\
\text { registered by } \\
\text { authorities }\end{array}$ & $\begin{array}{l}\text { Yes / } \\
\text { depends }\end{array}$ & $\begin{array}{l}\text { Semi- } \\
\text { regular }\end{array}$ & $\begin{array}{l}\text { Foreigners who are } \\
\text { waiting for a } \\
\text { renewal or a } \\
\text { regularization } \\
\text { usually keep } \\
\text { working while } \\
\text { waiting. In some } \\
\text { cases, there might } \\
\text { be de-alignment } \\
\text { between the issuing } \\
\text { of a permit and the } \\
\text { date of start / } \\
\text { continue a job. This } \\
\text { is usually } \\
\text { considered as not } \\
\text { irregular by } \\
\text { authorities; } \\
\text { Asylum seekers can } \\
\text { be prevented to } \\
\text { work for periods } \\
\text { that vary from } \\
0 \text { months to } 1 \text { year } \\
\text { or more depending } \\
\text { on the country } \\
\text { while waiting that a } \\
\text { decision is taken. }\end{array}$ \\
\hline & Visitors & $\begin{array}{l}\text { Visa-free and } \\
\text { tourist-visa }\end{array}$ & No & Irregular & $\begin{array}{l}\text { Foreigners who do } \\
\text { not need a visa to } \\
\text { enter or enter with a } \\
\text { tourist visa, and } \\
\text { then work } \\
\text { irregularly. }\end{array}$ \\
\hline
\end{tabular}


Table 8.2 (continued)

\begin{tabular}{|c|c|c|c|c|c|}
\hline \multirow[t]{4}{*}{ Nationality } & Residence status & $\begin{array}{l}\text { Registered by } \\
\text { authorities }\end{array}$ & $\begin{array}{l}\text { Entitlement } \\
\text { to work }\end{array}$ & $\begin{array}{l}\text { Nature of } \\
\text { employment }\end{array}$ & $\begin{array}{l}\text { Examples of } \\
\text { irregular } \\
\text { (undeclared/ } \\
\text { under-declared) } \\
\text { working conditions }\end{array}$ \\
\hline & Irregular & $\begin{array}{l}\text { Forged } \\
\text { papers/ } \\
\text { identity }\end{array}$ & $\begin{array}{l}\text { Formally } \\
\text { yes }\end{array}$ & $\begin{array}{l}\text { Regular/ } \\
\text { irregular }\end{array}$ & $\begin{array}{l}\text { Until detected, } \\
\text { foreigners with } \\
\text { forged papers might } \\
\text { work and live as } \\
\text { regularly residing } \\
\text { ones. }\end{array}$ \\
\hline & Irregular & $\begin{array}{l}\text { Lost status: } \\
\text { no renewal, } \\
\text { end of period } \\
\text { of study, end } \\
\text { of family } \\
\text { permit for } \\
\text { those aged } \\
18+, \text { end of } \\
\text { seasonal } \\
\text { permit; } \\
\text { rejected } \\
\text { asylum } \\
\text { application }\end{array}$ & No & Irregular & $\begin{array}{l}\text { Foreigners who do } \\
\text { not satisfy anymore } \\
\text { conditions to obtain } \\
\text { a residence permit } \\
\text { might decide to stay } \\
\text { and work } \\
\text { informally, for } \\
\text { example if they } \\
\text { have an irregular } \\
\text { job which is not } \\
\text { valid to obtain the } \\
\text { permit or if they are } \\
\text { looking for a job } \\
\text { after finishing the } \\
\text { study period. }\end{array}$ \\
\hline & Irregular & $\begin{array}{l}\text { No status } \\
\text { (never had) }\end{array}$ & No & $\begin{array}{l}\text { Irregular / } \\
\text { none }\end{array}$ & $\begin{array}{l}\text { Foreigners who } \\
\text { over-stay the length } \\
\text { of the visa or enter } \\
\text { irregularly, and } \\
\text { work irregularly. } \\
\text { Some can avoid } \\
\text { working and relying } \\
\text { of family networks } \\
\text { (e.g. family } \\
\text { members reunified } \\
\text { without } \\
\text { authorization, } \\
\text { including children). }\end{array}$ \\
\hline
\end{tabular}


Table 8.2 (continued)

\begin{tabular}{|c|c|c|c|c|c|}
\hline Nationality & Residence status & $\begin{array}{l}\text { Registered by } \\
\text { authorities }\end{array}$ & $\begin{array}{l}\text { Entitlement } \\
\text { to work }\end{array}$ & $\begin{array}{l}\text { Nature of } \\
\text { employment }\end{array}$ & $\begin{array}{l}\text { Examples of } \\
\text { irregular } \\
\text { (undeclared/ } \\
\text { under-declared) } \\
\text { working conditions }\end{array}$ \\
\hline & Irregular (transit) & No status & No & $\begin{array}{l}\text { None / } \\
\text { irregular }\end{array}$ & $\begin{array}{l}\text { Transit irregular } \\
\text { migrants who enter } \\
\text { irregularly and } \\
\text { avoid controls } \\
\text { while trying to } \\
\text { reach another } \\
\text { country, they might } \\
\text { sometimes engage } \\
\text { in informal jobs to } \\
\text { survive during the } \\
\text { journey and can } \\
\text { rely on smuggling } \\
\text { services to reach } \\
\text { their destination. }\end{array}$ \\
\hline & $\begin{array}{l}\text { Irregular / } \\
\text { tolerated }\end{array}$ & $\begin{array}{l}\text { Registered } \\
\text { because } \\
\text { detected at } \\
\text { some point }\end{array}$ & No & Irregular & $\begin{array}{l}\text { Foreigners whose } \\
\text { removal/ } \\
\text { deportation is } \\
\text { suspended } \\
\text { (formally or not) } \\
\text { and therefore are } \\
\text { known to } \\
\text { authorities but } \\
\text { tolerated }\end{array}$ \\
\hline
\end{tabular}

Source: Authors' adaptation from (OECD 2000; Kovacheva and Vogel 2009)

\subsection{European Labour Market Dynamics and the (Irregular) Migrant Work}

Adopting a structural approach in looking at European labour markets to understand where most common forms of irregular work arise which involve the migrant workforce, a special attention is placed by a consistent body of work to the role of institutional and context-specific factors, such as labour market structures and regulations, size and pervasiveness of underground economy, welfare regimes or immigration policies, typically adopting comparative research approaches (Piore 1979; Kogan 2006; Reyneri and Fullin 2011).

As initially theorized by Piore (1979), looking at the segmentation of the labour market in the destination country helps explaining how migrants integrate into local labour markets and in which ways migrants can be involved in irregular forms of work. According to a consistent body of research based on Piore's work on "dual labour market", migrants' labour market integration process is influenced by the segmentation level of labour markets at destination, in which a "primary" segments 
with relatively high-pay, highly-skilled and stable jobs can thrive and rely on a "secondary" segments with low paid, low-skilled and highly volatile jobs, with low possibility of upward mobility, which are often filled by migrant workforce (Reyneri and Fullin 2011). In many recent official reports at the EU level, labour market segmentation is indeed recognized as a persistent feature that needs targeted interventions across EU countries (EC 2015b, 2017).

Although there is no single definition of segmentation with regards to the specific indicators and measures that needs to be taken into account, various work have looked at the characteristics of the workforce in terms of age structure, age, race, migration status, skills, sectors of specialization, and so on) together with a number of structural features of local labour markets (ageing dynamics of the workforce, levels of female labour participation, the proportion of highly- versus low-skilled occupations, the prevalence of small versus big firms, the proportion of selfemployment and temporary contracts, the prevalence of subcontracting procedures in some sectors) of the economic system as whole, as for example the tax and social contribution wedge (the proportional difference between the worker's cost for the employer and the worker's net wage), of the public administration (the level and quality of public services to support economic activity and family reproduction, the level of efficiency and/or bureaucratization of administrative procedures), of immigration policies (the degree of enforcement and controls), the social acceptance of economic informality (Reyneri 2001; Ambrosini 2013; Düvell 2006), and the economic cycle.

Moreover, social norms are often mentioned in discussions on where and why irregular employment and irregular migration are more likely to be found: scholars often agree that in some southern European countries it is easier to avoid compliance to norms than in countries of central and northern Europe, and especially in sectors like agriculture, construction, small or family firms in the manufacturing sectors, services, and self-employment (see for instance Ambrosini 2015). Indeed, these countries are internationally rated as those with most rigid state regulation of economic activity but with low enforcement levels and widespread free-riding behaviours. Nevertheless, an important share of the estimated irregular employment is also found in central and northern European countries. In each country, depending on the characteristics listed above, the interplay between irregular activities and immigration flows might generate different levels and combinations and create special niches for informal labour of irregular migrants to flourish.

\subsubsection{A Steady Demand for Low-Skilled, Precarious and Cheap Workers Within a Restrictive Migration Environment}

Over the last 30 years, tensions between labour market demands and increasingly selective immigration policies have become evident in most industrialized countries. In the EU context, efforts to strengthen controls, curb irregular migration and 
establish a common migration and asylum system have been on the rise especially since the beginning of the 2000s, reducing regular entry channels and officially promoting only highly-skilled immigration. While many European countries-perhaps with the exception of the UK-seem unable to compete in the global battle for brains (Campanella 2014), their need for immigration is structural and likely to remain at high levels in the medium term. In the words of the European Commission, "The EU is [...] facing a series of long-term economic and demographic challenges. Its population is ageing, while its economy is increasingly dependent on highlyskilled jobs. Furthermore, without migration the EU's working age population will decline by 17.5 million in the next decade. Migration will increasingly be an important way to enhance the sustainability of our welfare system and to ensure sustainable growth of the EU economy." (EC 2015a, b: 14).

As for low-skilled jobs, the chronic mismatch between national restrictive policies and economic demand for cheap and flexible labour in many sectors such as construction, cleaning, caring, catering, and tourism has led to the toleration of certain levels of 'physiological' irregular migration (Ruhs and Anderson 2006; Ambrosini 2013).

Already in the mid-1990s some researchers (see for instance Arango and Baldwin-Edwards 1999) were pointing to the structural imbalances in southern European labour markets where a relatively high level of domestic unemployment combined with high levels of immigration. Migrants were indeed taking the jobs that natives were reluctant to fill because of both low pay and low prestige. This was particularly the case in labour-intensive and seasonal sectors, as well as in the caring and cleaning sector, as native women engaged in paid work leaving the care needs of old and young family members uncovered (Reyneri 2004; Ribas-Mateos 2004). The same sectors are typically those where informal work thrives and is tolerated, especially when the workplace is a private space and inspections are virtually non-existent.

Additionally, bureaucratic hurdles to permits' renewal often may lead migrants to periods of undocumented/illegal stay (for example, because of unemployment). Several studies have confirmed that migrants with more precarious and unstable work and residence conditions can fall into vicious circles of irregular stay and informal employment until a regular occupation is found with characteristics that allow them to regain their regular migration status. In this sense, informal employment may be part of such adaptive responses to difficulties posed by migration rules that keep a close connection between legal stay and a registered job (Reyneri 2001).

However, as more recent research on the UK has shown (Anderson 2010), immigration controls that are supposed to protect migrant workers from exploitation and locals from unfair competition can create an environment of informal work as they institutionalise vulnerability and uncertainty. Migrant workers with insecure status or with restricted socio-economic rights-restrictions on family reunification, restricted access to housing benefits or family allowances-live in a status of precariousness that conduces to informal and exploitative work. To avoid the risk of being fired, they are willing to accept to work overtime or in unfavourable night/ weekend shifts with little pay, or to be falsely self-employed. Especially when they 
have no family and only short-term prospects of staying at destination, they might prefer some additional cash in hand than the protection of labour and welfare rights which are often non-portable. The dependence of the migrant worker on the employer creates incentives for exploitation and irregular work arrangements.

As outlined earlier, the overall demand for migrant work in Europe has been geared towards sectors where informality is structurally high. Furthermore, after the EU enlargements in 2004 and 2007, citizens of the new member states provided for a legal migrant labour force, competing with third-country nationals as they were freed from the need of permit renewal. EU citizenship has not been sufficient to protect these intra-EU migrants from severe exploitation and irregular work. Studies on agriculture in Italy and Spain, for instance, show that EU migrants, particularly women, work under extreme conditions of vulnerability and have little access to their rights. Issues like having networks, not being isolated at work, or knowing the language are more important or equally important as being an EU citizen, regularly present in the destination-country (Palumbo and Sciurba 2018; Mesa de la Integración 2018).

Asylum seekers with pending applications also experience special vulnerability (Lewis and Waite 2015). They may temporarily reside legally in the country but without the right to work for periods that vary from two months (Italy), to three (Germany, Austria, Switzerland), nine (France), or 12 (United Kingdom). In most of the cases, asylum seekers might look for jobs in construction, agriculture, or other sectors, with a view of earning some income while waiting for the outcome of their request. These legal residents with pending status are particularly alluring for unscrupulous employers as they pose no danger in terms of breaching migration law but offer the possibility of lowering labour costs for jobs that do not require a high degree of specialisation or language skills, or for jobs that are unstable, seasonal, and badly paid.

Semi-compliance involving legal stay and irregular work can be an intentional strategy for employers and (migrant) workers. As already argued, there seems to be an "economically optimal level of illegal migration" (Boswell and Straubhaar 2003) and notion that immigration can "grease the wheels" (Borjas 2001) of labour markets even in its irregular form. Keeping migrants in an irregular employment condition, when they cannot be contained, seems to add particular, though unfair, economic advantages to their presence (Düvell 2006).

Moreover, the employment of irregular migrants does not only involve the convenience of single employers or private households but has economic and social impacts on the whole society. The presence of irregular foreign residents in a country increases the local labour supply and can represent a form of unfair competition against the local workforce, leading to a sort of crowding out or substitution of regular workers for occupations at the very bottom of the skill and wage scales. Nevertheless, the overall economic effect of irregular migrant workers is far from being clear and should be tested case by case depending on the overarching labour market structure. Several empirical studies suggest that immigrants are complements rather than competitors in their host countries' labour market (Venturini and Villosio 2008). Overall, a real competition between migrants and natives in general 
has barely been proven as irregular migrants have skills and characteristics different from the local workforce and can hardly replace it at all levels and in all sectors. Interactions between migrants and the host labour markets can determine a strong specialization of (irregular) migrants in sectors not adequately filled by local workforce. In filling these gaps, migrants allow locals-especially in the traditional labour markets of southern Europe- to up-scale and reach higher positions in the labour market (Fullin and Reyneri 2011). Moreover, the overcrowding argument has lost its plausibility for almost all European countries, whose working-age populations are decreasing.

Even during the European economic downturn, despite the rhetoric on brain drains from hard-hit countries and replacement of migrants by natives, no largescale movements of native workers to the lowest-ranked jobs and occupations to find employment were observed (Triandafyllidou and Isaakyan 2016). Although data for a systematic analysis of the effect of the economic recession on the composition of workforce by sectors and skill-levels are yet to be analysed comparatively across Europe, the most visible effect is the higher risk of unemployment of migrants than natives and the increase in the number of non-renewals of work permits, especially in the construction and industrial sectors. In some cases, there might have been a displacement effect of third-country nationals by EU migrants (agriculture, domestic, and care work); in others, losing residence and work status might have increased the irregular migrant population (Triandafyllidou 2014).

\subsubsection{Irregular Migrant Work: A Sectorial Approach}

Today, as in the early 2000s, the highest concentration of irregular foreign workers is found in agriculture, manufacturing, construction, public works (through public procurement and sub-contractors), and the service sector (tourism, entertainment, hospitality) (ILO 2013). To these, the big return to paid domestic labour worldwide and specifically in Europe, recently described as the "defamilialization of care" (Estévez-Abe and Naldini 2016), has to be added. Agriculture, tourism, and construction are characterized by high competition, a certain degree of seasonal fluctuations and low profit margins, made possible only by squeezing labour costs. In some cases, informal labour arrangements are favoured by the nature of the workplace, which is difficult to control or not visible (construction sites, farms, cleaning companies, and services provided through internet) (Triandafyllidou 2013). In others, employers with or without employees are themselves hardly structured and observable (small family businesses, households, and self-employed service providers).

To delve deeper into those niches where irregular work of irregular migrants are more likely to be found, the following subsections combine a sectorial approachdiscussing the prevalent dynamics of the irregular work of irregular migrants in the domestic and care sector, agriculture, and the construction sectors-by presenting some country-case examples. The three selected sectors show different labour and 
migration dynamics and different challenges: the domestic/care work takes place in a very personalised and 'private' domain; agriculture is a domain of temporary and informal work squeezed by large conglomerates in the agri-food business; and construction represents an area where again employment is unstable albeit not seasonal but rather tied to specific building projects and where multiple levels of subcontracting dominate.

Domestic and Care Work in the Home According to the ILO (2015), 80\% of migrant domestic workers are concentrated in high income countries $(9.1$ million out of the 11.5 million estimated). The observed increase of paid domestic work since the early 2000s is associated with at least two main trends shared by most of the advanced economies in Europe and elsewhere: population ageing and the increase in labour market participation of (native) women.

Especially in countries where there is low male participation in reproductive roles and household chores, the greater presence of women in the labour market depends, in the abstract, on the provision of private care and domestic services by someone else in the home. Hence, the availability of cheap, irregular work to provide for domestic and care work has played a key role in allowing more women to find paid employment outside the home (Ambrosini 2013) in those countries with more unbalanced gender relations and with poorly-developed social safety nets for both child and elderly care (Estévez-Abe and Naldini 2016).

Different countries have opted for different solutions to ensure financial viability of long-term care provisions for the elderly, coping with generalized welfare cuts, and growing care needs at the same time. Several studies have shown that different welfare and care regimes led to different types of migration, care arrangements, and care markets, with Italy and other southern European countries relying on a specific division of labour among family migrant carers (mostly female), and skilled native workers (Bettio et al. 2006). More specifically, in a recent study on Italy, the UK, and the Netherlands (Van Hooren 2012), the Italian familistic care regime is found to provide cash allowances to families without controls on how they spend the funds, which incentivises the emergence of a 'migrant-in-the-family' model of care, with families becoming employers of migrant care workers. In the British care regime, where care is increasingly transformed into cash payments, a double market emerges with more affluent families that resort to the private market for paid care and less affluent families that use care allowances to cover food or transportation costs and directly provide care to the elderly person, only in few cases with the help of a paid care worker. As the UK government monitors how the allowances are spent, hiring an irregular migrant care worker is not an option. In the Dutch case, care services are provided by the public welfare system and there is thus no private market of care services, with a very low demand for migrant care workers (Van Hooren 2012, 141-42). Also, in a larger study on the care sector, Da Roit and Weicht (2013) find that Germany, Austria, Italy, and Spain rely mainly on migrant care workers at home, while the Netherlands, Norway, Sweden, and the UK tend to rely more on the formal sector and on services provided by public or private entities. 
The distinction between familistic and liberal regimes can also partially explain the cases of Austria and Germany with the limited public resources, the public preference for cash programmes, and the segregation of migrants in low skilled jobs (Da Roit and Weicht 2013, 479). The scarcity of cash-for-care programmes is complemented by a high level of informal work arrangements mainly involving migrants (see also León and Pavolini 2014), which together with a strongly segregated labour market leads to a migrant-in-the-family model (Da Roit and Weicht 2013, 481). At the same time, when there are no uncontrolled cash benefits and no large informal economy, a migrant-in-formal-care model can arise, as in the case of the Netherlands, France, Sweden, and Norway. These factors alone are not sufficient though, as in the UK case where there is a strong presence of the private sector and formal care arrangements through private providers.

To summarize, the emergence of informal migrant work in the domestic home care sector is shaped by a combination of factors: total public expenditures on formal care services, the presence or absence of uncontrolled cash-for-care programmes, and the presence or absence of irregular migrants or indeed of migrants who can afford to work without a formal contract (EU citizens, TCNs with permanent permit, with a permit linked to their spouse or naturalized, and all those who do not need to prove to be employed in order to keep/ renew their residence permit).

Moreover, the intrinsic characteristics of domestic and care work in private households may exacerbate the specific barriers to information and understanding of administrative procedures and labour laws that are usually faced by migrants. Live-in migrant domestic workers tend more than others to be isolated from peers, service providers and the host society in general, with limited freedom of movement in the public sphere. Hence, they are hence more at risk of exploitation, abuse, lack of access to fundamental rights (privacy and dignity, freedom). Live-out immigrant workers too may experience the same kind of exclusion and marginalization if they are in irregular resident position (Triandafyllidou 2013). As recently recalled by (Marchetti and Salih 2017), this is a particularly gendered area of employment for migrant workers, attracting both irregular migrant women and regularly-residing migrant women who are nevertheless channelled to care or domestic work.

Agriculture When we look at the agricultural sector, the analysis of the labour dynamics intersects with the analysis of how the production of food and the management of natural resources have changed over recent decades, in relation to other sectors of the European economies and to other countries where rural communities still represent a significant share of the total population. Agriculture is still particularly relevant in EU countries of the south-Italy, Spain, Greece, Portugal, and France-where the management of the rural territory is central for agro-industry and the tourism sector. Despite its success in supporting production levels, the Common Agricultural Policy has achieved less satisfactory results on a social and environmental level, with rural populations affected by faster ageing and higher emigration rates than the average. Immigration has consistently filled the growing demand for seasonal, hard and low-paying work, as natives are reluctant to engage 
in agricultural labour because of its low prestige and profits and because of the general internal migration to urban areas. Regular and irregular migrant workers are now found in many local districts of agro-food production in almost all European countries, with conditions of work and residence that vary depending on the more general country-context of immigration (see among others Cillo and Toffanin 2014 on Italy; Scott et al. 2012 on the UK; Rye 2017 on Norway).

The connection with commercial networks, agro-entrepreneurs, intermediaries, and the final consumers push for lowering the prices of vegetables and fruits at any costs and with difficult traceability of products. The dynamics of irregular employment in agriculture are thus shaped by a number of factors that are not confined to labour migration management but rather have to do with the organisation of production and related sectorial labour market dynamics. The inherent seasonality of agricultural productions requires ultra-flexible mechanisms to regulate the existing workforce; workers should be available on call, be easily dismissed, work under adverse conditions, and have few prospects for upwards mobility. Moreover, international and national competition among large corporations in the retail and agrifood production chains creates pressure for lowering production costs at the lowest level of the chain, especially squeezing labour costs when all other production inputs-water, energy, fertilizers, and mechanization of processes-are put under control (Palumbo and Sciurba 2018).

In this context, migration policy plays an important role by restricting channels for legal labour migration with the aim of domestic electorates against the threads of a 'migration crisis' (Dines et al. 2018). At the same time though, they have an important side-effect of creating a plentiful young labour force available to work at extreme conditions, vulnerable to exploitation because of its irregular or insecure legal status (Lewis and Waite 2015; Amnesty International 2012).

In Ireland, the UK, Germany and the Nordic countries, the demand for agricultural labour has been largely met through intra-European migration from the newlyaccessed member states. While this migration was linked to seasonal contractual employment, recent research has shown that employment was formally legal but often exploitative, involving sub-standard conditions in terms of working hours, wages, and safety conditions. Potter and Hamilton (2014) document how mushroom pickers coming from the new member states worked initially without papers, either because they were unaware of the necessary documentation or because they trusted the employer's promise of subsequent regularization. In the case of the UK, concerns are growing over what will happen after Brexit, on whether there will be seasonal schemes to cater for a much-needed labour force from EU countries, incentives for native unemployed workers to take up jobs in the sector, or investments in increased automation (McGuinnnes and Garto Grimwood 2017).

In southern Europe, male and female migrants of different nationalities are concentrated in specific regions and local districts. Many of them are seasonal workers whose administrative position makes them more prone to abuses by employers. The quota system applied in Italy is not aligned with the real needs in cultivations which 
are highly dependent on the season and not always foreseeable, but always higher than what the formal entry quotas permit (Cillo and Toffanin 2014). Moreover, in the last few years there has been an increase in a particular kind of flexible migrant labour force in agriculture-that of migrants who have applied for protection and those with a regular refugee, subsidiary or humanitarian status - that has led to what has been defined as "refugeeization" of specific segments of the migrant labour force (Dines and Rigo 2015), which involves young and mostly male migrants from sub-Saharan Africa, North Africa and southeast Asia in Italy, Greece, Spain (see also Palumbo and Sciurba 2018).

Construction Construction is a volatile sector whose dynamics are strongly related to fluctuations of the local and national economic cycle, of energy and raw material prices, on political decisions on the use of land for new buildings or infrastructures, as well as on incentives for private demand/supply of new construction or renovation sites. Construction is a labour-intensive activity that is usually dominated by small firms with limited fixed capital, with the exception of some large companies that can manage entire building projects and often outsource single segments to smaller subcontractors (Bosch 2012). Labour is usually provided through temporary work agencies and specialized subcontractors, thus contributing to the creation of a competitive job market where workers can be summoned at short notice and where employment is certainly not stable (Ibid.). In the case of Europe, the issue of posted workers from southern and eastern European countries competing with local workers of central and northern European countries has gained public attention since the entry into force of the Posting of Workers Directive in 1996.

Hence, construction has evolved into a sector for mostly European migrant employment, especially in the case of Germany, the UK, and other northern European countries. On the other side, in Mediterranean countries like Italy, Greece or Spain, migrants from eastern Europe have traditionally filled the gap for cheap and flexible labour along with migrants from North Africa. In these countries, construction is a highly-segmented sector with a relatively small, highly-regulated force of workers, protected by trade unions and respecting the standards, plus a large peripheral, unregulated labour market that included a large number of irregular migrants. Spain stood out in particular because of the boom in residential construction of the 2000s which attracted a large number of immigrants, both regular and irregular (Fellini et al. 2007) that suffered from high unemployed in recent years. The same recurrent dynamics are found across southern Europe, with Albanians in both Greece and Italy, Georgians, Ukrainians, and Bulgarians in Greece,and Ukrainians, Poles; and Romanians in Italy and Spain. Such dynamics have also been found in the UK (Bloch 2013) and the Netherlands (Snel et al. 2015).

The match of offer and demand in construction initially takes place through word of mouth and later on through migrants themselves who become formal or informal subcontractors, with their own teams of co-workers providing their services to a native subcontractor. Employment is irregular when workers are irregular. However, upwards mobility to better-paid or more skilled position and/or to the creation of an 
independent enterprise for subcontracting is possible as workers regularize. Co-ethnic networks are crucial in this respect. Upward mobility has been more readily available to Poles, Bulgarians, and Romanians as they acquired EU citizenship, but the same was true for TCNs regularized through one of the large 'amnesty' programs implemented, for example, in Italy in the late 1990s and early 2000s. Nonetheless, regularizing the residence status did not necessarily mean a fullyregular employment too. More often, migrant construction workers were paid partly off-the-books to top up minimum wages, formally declared to receive social insurance coverage and the renewal of work permits. This has proven to be an important bargaining tool in the hands of subcontractors, both formal and informal, who brokered deals with big construction companies for suppressing the costs of labour.

Different dynamics were observable in northern Europe. Here, subcontracts and employment agencies played a crucial role for opening migrant employment channels. In Germany, posted worker arrangements and a massive entry of foreign workers in the construction sector happened already in the mid-to-late 1990s despite trade union protest (Fellini et al. 2007). In the British construction sector, massive migrant employment became common with the arrival of Polish workers after the 2004. Practices of subcontracting and bogus self-employment have been widespread in the sector (Caro et al. 2015). The role of transnational contractors that had good relations with construction firms in Germany, the Netherlands, or the UK is also crucial: these tend to have a flexible pool of migrant workers which they can tap to satisfy demand. Given the mobile nature of the work and the need to move between construction sites, oftentimes workers depend on their employer not only for work and pay but also for temporary housing and transportation. In her study, Berntsen $(2016,8)$ documents how such subcontracting arrangements with migrant workers are preferable as workers are there without their families, are housed in groups, and are thus more reliable and ready to work over time. On the other side, a study on Finland, Germany, and the Netherlands (Caro et al. 2015) found that this hyper-flexibility and high mobility reduces incentives for workers to integrate as more permanent migrants, and it is likely to segregate them within mono-national or mono-linguistic co-habiting solutions with colleagues.

Moreover, migrant workers in the construction sector are hardly protected by trade unions as the efforts of the latter to enforce labour standards generally leads to employer retaliation (Berntsen and Lillie 2014), with migrant workers "kicked out, have no job anymore and usually no accommodation, and find themselves, literally, standing in the streets without any protection" (trade union official cited in Berntsen $2016,10)$. As in the case of agriculture, contracts are not secure as the job market is very competitive, and wages are still competitive compared to earnings at origin, thus substandard conditions are the rule. The extent to which substandard conditions may amount to irregular work depends on the type of labour market regulation in each country. In Nordic countries where wages are determined predominantly by agreements between unions and firms instead of mandatory minimum wages applicable across the board, this may lead to opening up windows for low-wage 
competition and sub-standard conditions as typically migrant labourers are not unionized. Thus as Friberg et al. (2014) show, migrant workers may be exposed to such exploitative arrangements in Norway and Denmark. However, it should be noted that such arrangements are characterized more as atypical work rather than as irregular work tout court. Irregular work perhaps comes into play mostly in these countries when migrant workers (particularly from EU countries and hence with legal stay status) perform house maintenance tasks for private households.

To sum up, irregular migrant employment is difficult in the construction sector particularly when it comes to large construction sites. However, the concern for substandard conditions that verge on exploitation and illegality is widespread, as migrant workers are generally not sufficiently protected by trade unions or collective because of the highly competitive and inherently unstable nature of the construction job market. In this context, subcontractors and employment agencies can provide both more and housing thus making the overall migration project viable and profitable for migrant workers as wages are still superior to those at home.

Irregular employment in construction is more likely in small sites, in private household maintenance, and also more generally in southern European countries where the deep economic crisis has hit the construction sector particularly hard since 2008, leading to massive unemployment among migrant workers (particularly men). Under such conditions wages have fallen significantly and informal work abounds, while third country nationals previously employed might have been unable to renew their permits and might have decided to return (see Mai 2011 on Italy and Albania).

More comparative and sectoral studies would be needed to see what is happening during the fragile economic recovery of southern European countries particularly hit by the crisis since 2008 on one hand, and how the workers' and contractors' reaction to Brexit are impacting posted workers from eastern Europe in the UK, on the other.

\subsection{Concluding Remarks}

This chapter aimed to show that irregular migration has a close interactive relationship with demand for a cheap and flexible labour force in specific sectors of western and southern European labour markets. The first part of this chapter reviews critically the different ways in which irregular stay status and irregular work status intertwine to produce different typologies of irregularity. We point to the role of third actors such as employment agencies or subcontractors in this complex landscape. The chapter thus shows the complex dynamics of demand for irregular work which include both long-term structural factors linked to specific labour market sectors and migration policies that do not properly respond to labour market needs but rather create more precariousness, vulnerability, and irregularity. 
The long-term structural factors vary in different employment areas as this chapter shows by reviewing domestic and care work, agriculture and construction. For domestic and care work in the private home, an important role is played by the chronic underfunding of public welfare services and the privatisation of care in western and southern countries. In agriculture, the situation is characterised by the development of an intensive agriculture model in several areas of southern and western Europe for greenhouse productions and a parallel pressure on the market for low prices in vegetables and fruits. The harsh working conditions, the seasonality of jobs, the existence of multiple intermediaries, and the power of big supermarket chains to squeeze prices in order to maximise profits lead to a context where migrant workers are the weakest link in the chain, the one more prone to exploitation. Structural factors in the construction sector to some extent resemble those of agriculture: the sector is not seasonal, but it is volatile, often characterized by long sub-contracting chains and project-based, with frequent changes of employers.

All these factors create conditions of migrant workers' vulnerability in these sectors, as jobs are private (in domestic work) and inherently unstable (in agriculture and construction), and the. There is difficulty for workers to become unionised and hence know their rights and have access to them.

Migrant workers come to this context characterised by exploitation and precarity as well as harsh working conditions (hard manual work, unsocial hours, low pay, low prestige) and offer a flexible and exploitable labour force. This is particularly the case for undocumented migrants, asylum seekers whose cases are still pending, and especially for women migrants with family responsibilities. The lack of legal migration channels in general (for private domestic/care work and construction) or the existence of seasonal schemes that tie the worker to the employer (so as to guarantee to be called again the following year) leave the migrant worker vulnerable to the whims of unscrupulous employers. The difficulty of monitoring private homes as workplaces and remote agricultural areas further exacerbate these phenomena in domestic/care work and agriculture.

Addressing irregular migrant employment depends more upon labour market reforms that would eliminate or reduced the structural factors of demand for such work rather than on migration control to reduce the available, exploitable, and vulnerable workforce. Indeed, the enforcement of employment legislation, controls, inspections, verification of contracts, working conditions, accommodation, actual pay (Scott et al. 2012) are recurrently found in all policy documents at the national and European levels, offering different recommendations depending on the sector and the specific type of intersection between irregular work and irregular migration that we have described in the previous section (Wagner and Berntsen 2016). Within this context of combatting irregular work, there is a need to open up predictable and neat legal migration channels for workers in those sectors where demand for migrant workers is high and where domestic supply is low. Such channels would also safeguard the rights of native workers employed in these sectors as they would reduce the vulnerability of (irregular) migrant workers and would help guarantee labour standards (Ambrosini 2013). 
Today there is also a deepening concern that recently arrived migrants and asylum seekers from the 2015-2017 flows might offer a pool of cheap and flexible workers who will be engaged in irregular work as their legal status may be unclear while they will feel the urgent need to make a living and provide for their families. A protracted waiting period for asylum seekers in process, without a formal right to work, may push them inadvertently into irregular employment as housing and inkind allowances while the asylum process is ongoing may not be sufficient for them to make ends meet. In addition such protracted no-work waiting periods may make their insertion into the formal labour market later on, even more difficult (OECD 2016; Martín et al. 2016).

\section{References}

Ambrosini, M. (2013). Irregular migration and invisible welfare. New York: Palgrave Macmillan.

Ambrosini, M. (2015). From "illegality" to tolerance and beyond: Irregular immigration as a selective and dynamic process. International Migration, 54(2), 144-159. https://doi.org/10.1111/ imig. 12214.

Amnesty International. (2012). Exploited labour. Migrant workers in Italy's agricultural sector. London: Amnesty International. https://www.amnesty.org/en/documents/EUR30/020/2012/ en/.

Anderson, B. (2010). Migration, immigration controls and the fashioning of precarious workers. Work, Employment \& Society, 24(2), 300-317. https://doi.org/10.1177/0950017010362141.

Arango, J., \& Baldwin-Edwards, M. (1999). Immigrants and the informal economy in southern Europe. London: Taylor \& Francis.

Berntsen, L. (2016, January). Reworking labour practices: On the agency of unorganized mobile migrant construction workers. Work, Employment \& Society. 0950017015617687. https://doi. org/10.1177/0950017015617687.

Berntsen, L., \& Lillie, N. (2014, June). Hyper-mobile migrant workers and Dutch trade union representation strategies at the Eemshaven construction sites. Economic and Industrial Democracy. 0143831X14537357. https://doi.org/10.1177/0143831X14537357.

Bettio, F., Simonazzi, A., \& Villa, P. (2006). Change in care regimes and female migration: The "care drain" in the Mediterranean. Journal of European Social Policy, 16(3). http://journals. sagepub.com/doi/pdf/10.1177/0958928706065598), 271-285.

Bloch, A. (2013, March). The labour market experiences and strategies of young undocumented migrants. Work, Employment \& Society. 0950017012460313. https://doi. org/10.1177/0950017012460313.

Borjas, G. J. (2001). Does immigration grease the wheels of the labor market? Brookings Papers on Economic Activity, 2001(1), 69-133.

Bosch, G. (2012). Building Chaos or cooperation: Scenarios for the future development of the construction industry. CLR News, p. 4.

Boswell, C., \& Straubhaar, T. (2003). The back door: Temporary migration and illegal employment of workers. Geneva: International Labour Office.

Campanella, E. (2014, 16 October). Come home, Europeans. Europe's brain drain problem is becoming a major crisis. Foreign Affairs. https://www.foreignaffairs.com/articles/ europe/2014-10-16/come-home-europeans

Caro, E., Berntsen, L., Lillie, N., \& Wagner, I. (2015). Posted migration and segregation in the European construction sector. Journal of Ethnic and Migration Studies, 41(10), 1600-1620. https://doi.org/10.1080/1369183X.2015.1015406. 
Cillo, R., \& Toffanin, T. (2014). Corporate social responsibility to prevent human trafficking. Immigrant workers in Italian agriculture. A mapping. Venice: University of Venice.

Da Roit, B., \& Weicht, B. (2013). Migrant care work and care, migration and employment regimes: A fuzzy-set analysis. Journal of European Social Policy, 23(5), 469-486. https://doi. org/10.1177/0958928713499175.

De Genova, N. (2004). The legal production of Mexican/migrant "illegality". Latino Studies, 2(2), 160-185. https://doi.org/10.1057/palgrave.1st.8600085.

Dines, N., \& Rigo, E. (2015). Postcolonial citizenships and the "Refugeeization" of the workforce: Migrant agricultural labor in the Italian Mezzogiorno. In Postcolonial transitions in Europe: Contexts, practices and politics, edited by Sandra Ponzanesi and Gianmaria Colpani. Lanham: Rowman \& Littlefield.

Dines, N., Montagna., N. \& Vacchelli, E. (2018). Beyond crisis talk: Interrogating migration and crises in Europe, Sociology, 52(3), 439-447. https://doi.org/10.1177/0038038518767372.

Düvell, F. (2006). Crossing the fringes of Europe: Transit migration in the EU's neighbourhood. Oxford: Centre on Migration, Policy and Society.

EC. (1998). Communication from the Commission (98) 219 final. Brussels: European Commission.

EC. (2015a). Communication from the Commission to the European Parliament, the Council, the European Economic and Social Committee and the Committee of the Regions - A European agenda on migration. In COM(2015) 240 final. Brussels: European Central Bank. http://eurlex.europa.eu/legal-content/EN/TXT/PDF/?uri=CELEX:52015DC0240\&from=EN.

EC. (2015b). Discussion paper for MLP expert workshop on measures to address labour market segmentation, European Commission. Luxembourg: Publications Office of the European Union.

EC. (2017). Joint employment report 2017, European Commission. Luxembourg: Publications Office of the European Union.

EMN. (2016). Illegal employment of third-country nationals in the EU (EMN Focussed Study 2016). Greece.

Estévez-Abe, M., \& Naldini, M. (2016). Politics of defamilialization: A comparison of Italy, Japan, Korea and Spain. Journal of European Social Policy, 26(4), 327-343. https://doi. org/10.1177/0958928716657276.

Fellini, I., Ferro, A., \& Fullin, G. (2007). Recruitment processes and labour mobility: The construction industry in Europe. Work, Employment \& Society, 21(2), 277-298. https://doi. org/10.1177/0950017007076635.

Friberg, J. H., Arnholtz, J., Eldring, L., Hansen, N. W., \& Thorarins, F. (2014). Nordic labour market institutions and new migrant workers: Polish migrants in Oslo, Copenhagen and Reykjavik. European Journal of Industrial Relations, 20(1), 37-53. https://doi. org/10.1177/0959680113516847.

Fullin, G., \& Reyneri, E. (2011). Low unemployment and bad jobs for new immigrants in Italy. Inernational Migration, 49(1), 118-147. https://doi.org/10.1111/j.1468-2435.2009.00594.x.

Galos, E., Laura, B., Harry, C., \& Naomi, G. (2017). Migrant vulnerability to human trafficking and exploitation: Evidence from the central and eastern Mediterranean migration routes. Geneva: International Organization for Migration (IOM).

Hussmanns, R. (2004). Measuring the informal economy: From employment in the informal sector to informal employment (Working Paper No. 53). Geneva: International Labour Office.

ILO. (2013). Labour inspection and undeclared work in the EU (Working Document No. 29). Geneva: LAB/ADMIN, International Labour Organization.

ILO. (2015). Making decent work a reality for migrant domestic workers (Domestic Work Policy Brief 9). Geneva: International labour Office.

Jordan, B., \& Düvell, F. (2002). Irregular migration. The dilemmas of transnational mobility. Cheltenham Glos: Edward Elgar Publishing Limited.

Kilkey, M., \& Urzi, D. (2017). Social reproduction in Sicily's agricultural sector: Migration status and context of reception. Journal of Ethnic and Migration Studies, 43(15), 2573-2590. https:// doi.org/10.1080/1369183X.2017.1286971. 
Kogan, I. (2006). Labor markets and economic incorporation among recent immigrants in Europe. Social Forces, 85(2), 697-721. https://doi.org/10.1353/sof.2007.0014.

Kovacheva, V., \& Vogel, D. (2009). The size of the irregular foreign resident population in the European Union in 2002, 2005 and 2008: Aggregated estimates. Hamburg: Hamburg Institute of International Economics.

León, M., \& Pavolini, E. (2014). "Social investment" or Back to "Familism": The impact of the economic crisis on family and care policies in Italy and Spain. South European Society and Politics, 19(3), 353-369. https://doi.org/10.1080/13608746.2014.948603.

Lewis, H., \& Waite, L. (2015). Asylum, immigration restrictions and exploitation: Hyper-precarity as a lens for understanding and tackling forced labour. Anti-Trafficking Review, 5, 49-67. www. antitraffickingreview.org.

Lewis, H., Dwyer, P., Hodkinson, S., \& Waite, L. (2015). Hyper-precarious lives: Migrants, work and forced labour in the global north. Progress in Human Geography, 39(5), 580-600. https:// doi.org/10.1177/2F0309132514548303.

Mai, N. (2011). Reluctant circularities: The interplay between integration, return and circular migration within the Albanian migration to Italy (METOIKOS project research report). Florence: European University Institute. http://www.eui.eu/Projects/METOIKOS/Documents/ CaseStudies/METOIKOSItaloAlbaniancasestudyreport.pdf.

Marchetti, S., \& Salih, R. (2017). Policing gender Mobilities: Interrogating the "feminisation of migration" to Europe. International Review of Sociology, 27(1), 6-24. https://doi.org/10.1080 /03906701.2017.1303966.

Martín, I., Sona, K., Isilda, M., Hermine, V., Michael, W., Rebecca, W., Giulia, S., et al. (2016). Mapping labour market integration support measures for asylum seekers and refugees: Policies and practices in EU member states. In REFMISMES research report. Florence: Bertelsmann Stiftung and Migration Policy Centre.

McGuinnnes, T., \& Garto Grimwood, G. (2017). Migrant workers in agriculture (Briefing Paper 7987). London: House of Commons Library. https://www.google.it/url?sa=t\&rct=j\&q=\&esr $\mathrm{c}=\mathrm{s} \&$ source $=$ web $\& \mathrm{~cd}=1 \& \mathrm{cad}=\mathrm{rja} \& u a c t=8 \& v e d=0$ ahUKEwjbkOyZ2_PZAhWGzaQKHXGDYkQFggnMAA\&url=http $\% 3 \mathrm{~A} \% 2 \mathrm{~F} \% 2$ Fresearchbriefings.files.parliament. uk\%2Fdocuments\%2FCBP-7987\%2FCBP-7987.pdf\&usg=AOvVaw3aZykO26HAH2atny1P D6p3

Merler, S., \& Hutl, P. (2015, March 2). Welcome to the dark side: GDP Revision and the Non-Observed Economy | Bruegel. Bruegel (blog). http://bruegel.org/2015/03/ welcome-to-the-dark-side-gdp-revision-and-the-non-observed-economy/

Mesa de la Integración. (2018). Realidad de los asentamientos en la provincia de Huelva., Report available at https://www.apdha.org/realidad-asentamientos-provincia-de-huelva/. Last Accessed on 5 Jan 2020.

OECD. (2000). Combating the illegal employment of foreign workers. Paris: OECD Publishing.

OECD. (2002). Measuring the non-observed economy: A handbook. Paris: Organisation for Economic Co-operation and Development. http://www.oecd-ilibrary.org/content/ book/9789264175358-en.

OECD. (2004). Employment outlook. Paris: OECD Publishing.

OECD. (2016). Making integration work: Refugees and others in need of protection. Paris: OECD Publishing. https://doi.org/10.1787/9789264251236-en

Palumbo, L., \& Sciurba, A. (2018). The vulnerability to exploitation of women migrant Workers in Agriculture in the EU: The need for a human rights and gender based approach (European Parliament Study 604966). Brussels: Policy Department for Citizens' Rights and Constitutional Affairs. http://cadmus.eui.eu//handle/1814/55444.

Piore, M. (1979). Birds of passage. Migrant labor and industrial societies. Cambridge: Cambridge University Press.

Portes, A. (1978). Introduction: Toward a structural analysis of illegal (undocumented) immigration. The International Migration Review, 12(4), 469-484. https://doi.org/10.2307/2545446. 
Potter, M., \& Hamilton, J. (2014, April). Picking on vulnerable migrants: Precarity and the mushroom industry in Northern Ireland. Work, Employment \& Society, 0950017013510760. https:// doi.org/10.1177/0950017013510760.

Reyneri, E. (2001). Migrants in irregular employment in the Mediterranean countries of the European Union (International Migration Paper 41). Geneva: International Labour Office. http:// www.ilo.org/global/topics/labour-migration/publications/WCMS_201875/lang\%2D\%2Den/ index.htm

Reyneri, E. (2004). Immigrants in a segmented and often undeclared labour market. Journal of Modern Italian Studies, 9(1), 71-93. https://doi.org/10.1080/1354571042000179191.

Reyneri, E., \& Fullin, G. (2011). Labour market penalties of new immigrants in new and old receiving West European countries. International Migration, 49(1), 31-57.

Ribas-Mateos, N. (2004). How can we understand immigration in Southern Europe? Journal of Ethnic and Migration Studies, 30(6), 1045-1063. https://doi.org/10.1080/1369183042000286 241.

Ruhs, M., \& Anderson, B. (2006). The origins and functions of illegality in migrant labour markets: An analysis of migrants, employers and the state in the UK (Working Paper 30a. COMPAS). https://www.compas.ox.ac.uk/media/WP-2006-030a-Ruhs-Anderson_Illegality_ Migrant_Labour_Markets.pdf

Rye, J. F. (2017). Negotiating neoliberalism: Informalisation and Reformalisation of industrial relations in Norway's agricultural industry in the 21st century. Population, Space and Place, 23(7), n/a-n/a. https://doi.org/10.1002/psp.2042.

Scott, S., Craig, G., \& Geddes, A. (2012). Experiences of forced labour in the UK food industry. York: Joseph Rowndtree Foundation. https://www.jrf.org.uk/report/ experiences-forced-labour-uk-food-industry.

Snel, E., Faber, M., \& Engbersen, G. (2015). Civic stratification and social positioning: CEE labour migrants without a work permit. Population, Space and Place, 21(6), 518-534. https:// doi.org/10.1002/psp.1846.

Triandafyllidou, A. (2013). Irregular migrant domestic Workers in Europe. Who cares? (Research in migration and ethnic relations series). Aldershot: Ashgate Publishing, Ltd.

Triandafyllidou, A. (2014). Migrant livelihoods during the Greek crisis: Coping strategies and the decision to return. Mondi Migranti, 3, 7-30. https://doi.org/10.3280/MM2014-003001.

Triandafyllidou, A., \& Bartolini, L. (2016). Irregular employment of migrant workers in Europe. Paper prepared for OECD, unpublished. Paris.

Triandafyllidou, A., \& Bartolini, L. (2017). Irregular migrants and rejected asylum seekers: Conceptual and policy challenges for Europe (Autumn Academy 2017). Oxford: University of Oxford.

Triandafyllidou, A., \& Isaakyan, I. (Eds.). (2016). High skill migration and recession. Palgrave Macmillan UK. https://doi.org/10.1057/9781137467119.

Triandafyllidou, A., Bartolini, L., \& Guidi, C. F. (2019). Exploring the links between enhancing regular pathways and discouraging irregular migration; a discussion paper to inform future policy deliberations, Geneva: IOM., available at: http://cadmus.eui.eu/handle/1814/61251

UNHCR, UNICEF, and IOM. (2018). Refugee and migrant children in Europe - Overview of trends 2017. Geneva: UNHCR, UNICEF and IOM. http://migration.iom.int/docs/Infographic_ Children_and_UASC_overview_2017.pdf

Van Hear, N., Brubaker, R., \& Bessa, T. (2009). Managing mobility for human development: The growing salience of mixed migration. Published in: Human Development Research Paper (HDRP) Series, Vol. 20, No. 2009, available at: https://mpra.ub.uni-muenchen.de/19202/. Last Accessed 5 Jan 2020.

Van Hooren, F. J. (2012). Varieties of migrant care work: Comparing patterns of migrant labour in social care. Journal of European Social Policy, 22(2), 133-147. https://doi. org/10.1177/0958928711433654.

Venturini, A., \& Villosio, C. (2008). Labour-market assimilation of foreign workers in Italy. Oxford Review of Economic Policy, 24(3), 517-541. https://doi.org/10.1093/oxrep/grn030. 
Vickstrom, E. (2014). Pathways into irregular status among Senegalese migrants in Europe. International Migration Review, 48(4), 1062-1099.

Wagner, I., \& Berntsen, L. (2016). Restricted rights: Obstacles in enforcing the labour rights of mobile EU workers in the German and Dutch construction sector. Transfer: European Review of Labour and Research, 22(2), 193-206. https://doi.org/10.1177/1024258916636025.

Williams, C., Bejaković, P., Mikulić, D., Franic, J., Kedir, A., \& Horodnic, I. A. (2017). An evaluation of the scale of undeclared work in the European Union and its structural determinants: Estimates using the labour input method (SSRN Scholarly Paper ID 3092080). Rochester: Social Science Research Network. https://papers.ssrn.com/abstract=3092080.

Open Access This chapter is licensed under the terms of the Creative Commons Attribution 4.0 International License (http://creativecommons.org/licenses/by/4.0/), which permits use, sharing, adaptation, distribution and reproduction in any medium or format, as long as you give appropriate credit to the original author(s) and the source, provide a link to the Creative Commons license and indicate if changes were made.

The images or other third party material in this chapter are included in the chapter's Creative Commons license, unless indicated otherwise in a credit line to the material. If material is not included in the chapter's Creative Commons license and your intended use is not permitted by statutory regulation or exceeds the permitted use, you will need to obtain permission directly from the copyright holder.

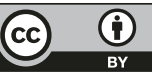

